\title{
PEMBELAJARAN MENGGAMBAR MOTIF BATIK PADA SISWA KELAS VIII DI SMP NEGERI 3 TANJUNG RAJA
}

\author{
Mita Yuliana, Djunaidi, Nofroza Yelli \\ Program Studi Pendidikan Seni Pertunjukan Universitas PGRI Palembang \\ Email: mitayuliana2004@gmail.com
}

\begin{abstract}
The purpose of this study was to determine the learning process of drawing batik motifs in grade VIII students at SMP Negeri 3 Tanjung Raja. The method used in this research is descriptive qualitative, which is a research method that seeks to describe a symptom, event, event, which is happening at the present time. The research objects in this study were teachers and students, namely teachers of the arts and culture subjects at SMP Negeri 3 Tanjung Raja and grade VIII students at SMP Negeri 3 Tanjung Raja. Data collection techniques in this study were observation, interviews, and documentation. Based on the evaluation activities that have been carried out, it can be concluded that the learning activities take place very well, it can be seen from the student learning outcomes achieved. The appropriate learning method is very learning activities to make students more ready to take part in learning to draw batik motifs.
\end{abstract}

Keywords: Learning, Drawing Batik Motif

\begin{abstract}
ABSTRAK
Tujuan dalam penelitian ini adalah untuk mengetahui proses pembelajaran menggambar motif batik pada siswa kelas VIII di SMP Negeri 3 Tanjung Raja. Metode yang digunakan dalam penelitian ini ialah deskriftif kualitatif, yaitu suatu metode penelitian yang berusaha mendeskriftifkan suatu gejala, peristiwa, kejadian, yang terjadi pada saat sekarang. Objek penelitian dalam penelitian ini adalah guru dan siswa yaitu guru mata pelajaran seni budaya di SMP Negeri 3 Tanjung Raja dan siswa kelas VIII di SMP Negeri 3 Tanjung Raja. Teknik pengumpulan data dalam penelitian ini adalah dengan observasi, wawancara, dan dokumentasi. Berdasarkan kegiatan evaluasi yang telah dilakukan, dapat disimpulkan bahwa kegiatan pembelajaran berlangsung dengan sangat baik dapat dilihat dari hasil belajar siswa yang dicapai. Metode pembelajaran yang tepat sangat kegiatan pembelajaran membuat siswa lebih siap dalam mengikuti pembelajaran menggambar motif batik.
\end{abstract}

Kata Kunci : Pembelajaran, Menggambar Motif Batik

\section{PENDAHULUAN}

Indonesia merupakan bangsa yang kaya dalam budaya. Kebudayaan adalah hasil karya manusia untuk mencapai sesuatu yang meliputi seni tari, seni musik, seni lukis, seni rupa, dan bagian-bagian yang indah dari kehidupan manusia. Kebudayaan harus diwujudkan dalam bentuk-bentuk 
nyata yang dapat difungsikan dan dimaknai. Salah satu wujud kebudayaan itu adalah batik. Batik di Indonesia merupakan suatu gabungan dari teknik, teknologi, serta pengembangan motif batik dan budaya yang ada di Indonesia. Warisan kebudayaan batik merupakan salah satu peninggalan sejarah yang memberikan ciri khas pada kebudayaan bangsa Indonesia.

Seni batik adalah penyaluran kreasi seseorang yang mempunyai seni yang tinggi. Untuk melestarikan budaya batik bisa melalui dunia pendidikan. Pendidikan merupakan salah satu aspek yang penting dalam kehidupan masyarakat dalam menciptakan sumber daya alam manusia yang berkualitas. Melalui pendidikan dapat meningkatkan mutu kualitas manusia yang kompeten dalam kegiatan pembelejaran yang optimal, sehingga tujuan pendidikan akan tercapai dengan maksimal mungkin sesuai dengan target yang diharapkan.

Proses belajar mengajar merupakan hal yang harus sangat diperhatikan dalam penyelenggaraan pendidikan di suatu lembaga pendidikan baik di jenjang pendidikan dasar, pendidikan menengah pertama, pendidikan menengah atas hingga perguruan tinggi. Pada dasarnya tujuan pendidikan di negara kita menghendaki tiga aspek perubahan yaitu pengetahuan (kognitif), keterampilan (psikomotorik), serta nilai dan sikap (afektif) dalam diri individu yang mengalami proses pendidikan.

Pembelajaran batik dalam karya seni rupa di SMP Negeri 3 Tanjung Raja banyak siswa yang kreatif dalam menggambar pola pada saat proses pembelajaran, metode dan teknik yang di gunakan oleh guru juga bervariasi. Dalam mendukung proses pembelajaran, sekolah juga memberi fasilitas sarana dan prasarana yang nyaman bagi siswa dan guru untuk menunjang proses pembelajaran, faktor lingkungan juga mendukung terbukti dengan adanya labolatorium khusus seni, sampai piala-piala prestasi siswa dalam karya seni tersimpan rapi di lemari labolatorium seni..

Berdasarkan uraian di atas maka peneliti tertarik untuk meneliti tentang Pembelajaran Menggambar Motif Batik Siswa Kelas VIII di SMP Negeri 3 Tanjung Raja. Masalah Penelitian yang ingin dikaji adalah: Bagaimanakah pembelajaran menggambar motif batik di SMP Negeri 3 Tanjung Raja? Adapun tujuan penelitian ialah untuk mengetahui proses pembelajarann menggambar motif batik siswa kelas VIII di SMP Negeri 3 Tanjung Raja.

\section{METODE}

Menurut Sugiyono dalam buku metode penelitian (2017:3) metode penelitian merupakan cara ilmiah untuk mendapatkan data dengan tujuan dan kegunaan tertentu. Metode kualitatif digunakan dalam penelitian ini. Secara teknik pengumpulan data berupa data observasi, wawancara dengan pelaku seni dan menggunakan pengumpulan data studi pustaka dan melalui dokumentasi pribadi, maupun dokumentasi yang diperoleh dari pelaku seni yang terkait. Data-data yang dikumpulkan selanjutnya akan dianalisis dengan mereduksi data, melakukan analisis terhadap hasil belajar siswa menggambar motif batik. Hasil analisis data akan diuraikan secara deskriptif dengan mengutamakan uraian yang sistematis.

Penelitian dilakukan di SMP Negeri 3 Tanjung Raja. Di sekolah tersebut terdiri dari 18 ruangan yang digunakan untuk proses belajar 
mengajar yaitu kelas VII, kelas VIII, dan kelas IX. Adapun fasilitas yang dimiliki oleh SMP Negeri 3 Tanjung Raja diambil dari data sekolah dari staf tata usaha adalah sebagai berikut : Perpustakaan SMP Negeri 3 Tanjung Raja memiliki satu ruang perpustakaan, Laboratorium terdapat satu ruang laboratorium IPA, Ruang Kepala Sekolah, Ruang Guru, Ruang OSIS, Ruang Pramuka, Ruang Multi Media, Ruang Kesenian, Ruang UKS, Ruang BK, Toilet / WC, Musholah, Lapangan Upacara, dan Kantin.

Proses belajar mengajar dilaksanakan mulai pukul 07.00 pagi, jadwal pulang nya berbeda-beda hari Senin dan Selasa pulang pukul 15.40, hari Rabu pukul 14.30, hari Kamis pukul 13.50, Hari Jumat Pukul 10.50 WIB. SMP Negeri 3 Tanjung Raja memiliki tenaga pengajar kurang lebih 50 orang dimana guru PNS berjumlah 40 Orang, Sedangkan untuk guru honor berjumlah 10 orang.

\section{HASIL DAN PEMBAHASAN}

Peneliti telah mendapat surat pengantar untuk melaksanakan penelitian dari Fakultas Keguruan dan Ilmu Pendidikan Universitas PGRI Palembang. Selanjutnya peneliti telah mendapat surat pengantar untuk melaksanakan penelitian dari Fakultas mengurus surat izin penelitian ke Kantor Dinas Pendidikan Kabupaten Ogan Ilir yang berada di Kompleks Perkantoran Terpadu Tanjung Senai Kecamatan Indralaya Kabupaten Ogan Ilir Sumatera Selatan, lalu surat pengantar tersebut diserahkan ke SMP 3 Tanjung Raja Kecamatan Indralaya Kabupaten Ogan Ilir, sebagai objek penelitian. Peneliti mendapatkan izin dari Kepala Sekolah untuk melakukan penelitian di kelas VIII.2 SMP 3 Tanjung Raja Kecamatan Indralaya Kabupaten Ogan Ilir, kemudian peneliti melakukan konsultasi dengan guru kelas.

Penelitian dilakukan selama empat kali pertemuan selama 1 bulan. Penelitian pertama dilakukan observasi ke sekolah dilakukan secara langsung didalam kelas, pertemuan kedua dilakukan secara online menjelaskan materi tentang batik. Selanjutnya pertemuaan ketiga juga dilakukan secara online guru menjelaskan menggambar pola batik seperti apa, alat dan bahan yang digunakan apa saja, macam-macam batik apa saja. Pertemuan keempat juga dilakukan secara online guru meminta siswa menggambar pola batik dan menjelaskan apa yang telah digambar oleh siswa kepada guru, gambar yang dibuat siswa dikirim melalui grup daring setelah itu guru melakukan wawancara dengan siswa.

\subsection{Deskripsi Data Observasi}

Pertemuan pertama dilaksanakan pada hari Rabu tanggal 23 September 2020. Pada pertemuan pertama peneliti melakukan observasi awal di sekolah SMP Negeri 3 Tanjung Raja. Tentang ruang lingkup yang ada di sekolah tersebut. Seperti menanyakan sejarah sekolah, staf dan tenaga pengajar yang honor maupun yang PNS, dan seluruh ruangan yang digunakan untuk proses belajar serta ruang yang dipakai untuk laboraturium dan perpustakaan.

Pertemuan kedua dilaksanakan pada hari Rabu tanggal 30 September 2020 di SMP Negeri 3 Tanjung Raja. Pada pertemuan ini peneliti mengamati saat guru mengajar secara online, untuk kegiatan pendahuluan, guru mengisi dengan kegiatan apersepsi yaitu mengucapkan salam, melakukan absensi kelas, memberikan informasi kompetensi dasar yang akan dicapai siswa, memberi motivasi belajar dan tanya jawab berbagai hal terkait dengan 
pengetahuan sesuai tentang materi yang akan disampaikan. Guru menjelaskan materi tentang konsep dan prosedur menggambar model. Setelah itu guru menyampaikan materi untuk pertemuaan berikutnya.

Pertemuan ketiga yang dilaksanakan hari Rabu tanggal 7 Oktober 2020. Pada pertemuan ini dilakukan secara online, guru memberi motivasi belajar dan tanya jawab berbagai hal terkait dengan wawasan sesuai tentang materi yang akan disampaikan, pada kegiatan inti guru menjelaskan pengertian batik, macammacam batik, dan guru mempraktikan cara-cara menggambar pola batik, alat dan bahan yang digunakan saat membatik. Setelah itu guru menyuruh siswa untuk menggambar pola batik.

Pertemuan keempat yang dilaksanakan hari Rabu tanggal 14 Oktober 2020. Pada pertemuan keempat ini masih dilakukan secara online, guru meminta siswa untuk menjelaskan apa yang di gambarnya serta siswa disuruh mengirimkan video menggambar pola batik melalui grup online. Siswa masih menyelesaikan tugas praktik dan peneliti melakukan kegiatan wawancara dengan salah satu siswa/i yang ada di kelas VIII. 2 yang perempuan bernama Indah Dewi sedangkan siswa laki-laki bernama Aldiansyah tentang mata pelajaran seni rupa menggambar motif batik dan juga peneliti melakukan wawancara dengan guru mata pelajaran Seni Budaya di SMP Negeri 3 Tanjung Raja. Yang bernama Nindira Damayanti, S.Pd.

\subsection{Hasil Analisis Data Observasi Terhadap Guru}

Untuk mengetahui hasil dari kegiatan proses pembelajaran yang dilaksanakan oleh guru dalam menyampaikan pelajaran penelitian berpedoman pada lembar observasi guru. Adapun data yang diperoleh melalui (lembar observasi guru dan siswa) dapat dilihat pada hasil observasi terhadap aktifitas guru dan aktifitas siswa pada tabel 3 dan 4. Hasil observasi terhadap guru menunjukan bahwa guru seni budaya di SMP Negeri 3 Tanjung Raja dalam proses belajar menggambar motif batik, peneliti mengamatinya dengan nilai baik.

Nilai

$\frac{\text { Jumlah Skor }}{\text { Jumlah aspek yang di amati }} \times 100 \%$
Nilai rata-rata $=\frac{19}{7} \times 100 \%$
Nilai rata-rata $=271.4$

rata-rata $=$

Dilihat dari hasil lembar observasi guru yang dilakukan terhadap guru seni budaya Ibu Nindira Damayanti, S.Pd, diatas didapatkan hasil bahwa skor 1 berjumlah tidak ada, skor 2 berjumlah 4 , skor 3 berjumlah 15. Skor 3 atau baik berjumlah 30 dimana skor 3 ( baik) setelah dicari hasilnya menggunakan rumus, maka didapatkan bahwa nilai rata-rata lembar observasi guru memiliki nilai 3 atau baik. Hal ini menandakan bahwa pembelajaran yang dilakukan dengan guru seni budaya di SMP Negeri 3 Tanjung Raja sudah baik. Sudah memenuhi kriteria-kriteria dalam penilaian yang ada di lembar observasi.

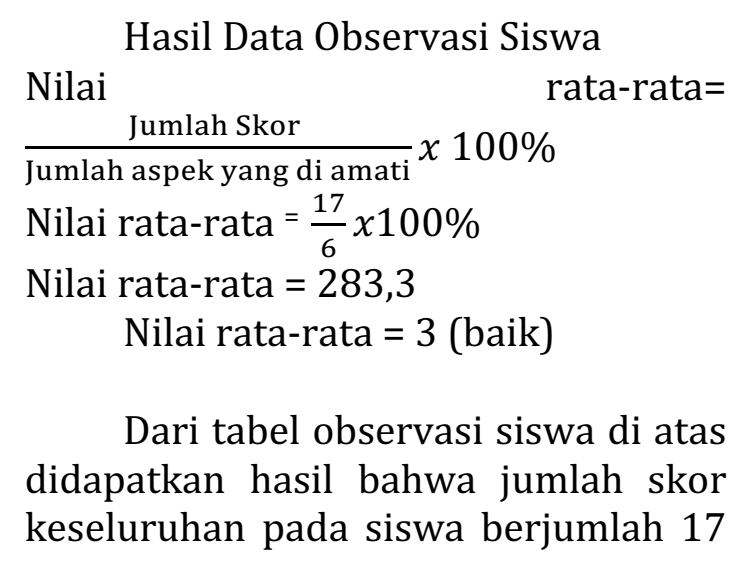


dan jumlah seluruh butir item pertanyaan adalah 6 pertanyaan, sehingga untuk mencari nilai rataratanya agar didapatkan hasil yang diharapkan digunakan rumus nilai ratarata= jumlah skor siswa dibagi jumlah pertanyaan dikali 100 didapatkan hasil yaitu 283,3 jika dibulatkan menjadi 3, dimana skor 3 nilainya baik.

Dapat diketahui bahwa proses pembelajaran secara umum termasuk dalam kategori baik, karena banyak guru dan siswa mendapatkan nilai baik. Lembar observasi peneliti gunakan untuk mengetahui keaktifan siswa dalam mengikuti pembelajaran menggambar motif batik.

\subsection{Hasil Data Wawancara dengan Guru dan Siswa}

Wawancara dilakukan guna memperoleh data pendukung penelitian yang dilakukan di dalam kelas, wawancara dilakukan dengan guru seni budaya dan salah satu siswa SMP Negeri 3 Tanjung Raja yang akan di deskripsikan sebagai berikut:

- Wawancara Guru Seni Budaya

Nama: Nindira Damayanti, S.Pd. Jabatan: Guru Seni Budaya SMP Negeri 3 Tanjug Raja.

Status: Guru Honorer.

Pertanyaan :

1) Apa persiapan yang Ibu lakukan sebelum memasuki materi?

2) Adakah kesulitan dalam mengajarkan siswa menggambar motif batik dan jika ada dimanakah letak kesulitannya?

3) Apakah ada kendala saat proses belajar mengajar motif batik?

4) Bagaimana cara Ibu untuk membangun motivasi anak dalam pembelajaran motif batik?
5) Bagaimana respon dari siswa dalampembelajaran menggambar motif batik?

Jawaban :

1) Saya mempersiapkan perangkat pembelajaran seperti RPP dan Silabus.

2) Dalam mengajarkan menggambar motif batik ini tidak ada kesulitan, karna siswa hanya menggambar motif batik yang sederhana dengan alat dan bahan yang sederhana juga.

3) Tidak ada kendala yang terlalu sulit, karena siswa sering berlatih dalam menggambar motif batik.

4) Untuk membangun motivasi anak harus selalu memberikan semangat dalam belajar agar dapat berprestasi dalam kegiatan akademik khususnya.

5) Respon siswa sangat senang karena dengan pembelajaran motif batik siswa lebih bisa berkreasi dalam meningkatkan bakat yang ada dalam dirinya.

\section{- Wawancara Siswa}

Nama pewawancara : Mita Yuliana Nama: Indah Dewi

Kelas: VIII. 2

Pada saat peneliti melakukan wawancara dengan siswa rata-rata jawabannya siswa hampir sama, sehingga peneliti hanya melampirkan hasil wawancara dengan beberapa siswa saja

Data Hasil Wawancara Siswa

Pertanyaan :

1) Apa anda menyukai pembelajaran menggambar motif batik? 
2) Apa yang membuat anda menyukai pembelajaran menggambar motif batik?

3) Apakah dengan menggambar motif batik ini mempermudah anda dalam meningkatkan kreatifitas Anda dalam menggambar motif batik?

4) Apakah dengan pembelajaran ini Anda bisa bersemangat dalam belajar?

Jawaban :

1) Ya, saya menyukai pembelajaran menggambar motif batik.

2) Yang membuat saya suka adalah saat menggambar pola batik nya itu tidak terlalu susah. Kita bisa meningkatkan kreatifitas kita untuk menggambar beberapa pola.

3) Ya, sangat mempermudah karena pembelajaran menggambar motif batik ini tidak terlalu sulit sehingga kita lebih bisa untuk meningkatkan kreativitas kita dalam menggambar.

4) Ya, sangat bersemangat karena dalam proses pembelajaran tidak membosankan.

Wawancara dilakukan pada guru mata pelajaran seni budaya dan salah satu siswa SMP Negeri 3 Tanjung Raja yang di jawab dengan baik. Dari hasil wawancara terhadap guru seni budaya dan siswa SMP Negeri 3 Tanjung Raja, pembelajaraan menggambar motif batik sudah tepat, mengingat bahwa respon seluruh siswa sangat baik mengenai pembelajaran menggambar motif batik.

Guru yang mengajar juga dianggap baik dalam menerapkan pembelajaran menggambar motif batik. Siswa menyukai pembelajaran menggambar motif batik karena dapat meningkatkan kreatifitas mereka dalam menggambar. Begitu pula dengan sarana dan prasarana di sekolah yang di anggap sudah memenuhi atau mendukung dalam proses pembelajaran.

\subsection{Hasil Analisis Data Dokumentasi}

Dari hasil penelitian selama 1 bulan yaitu dilakukan empat kali pertemuan, yang jatuh pada hari Rabu. Maka peneliti melakukan dokumentasi yang berupa foto-foto pada saat proses tanya jawab tentang materi menggambar model dan pembelajaran menggambar motif batik pada siswa kelas VIII di SMP Negeri 3 tanjung Raja.

Pembahasan pembelajaran menggambar motif batik di kelas VIII SMP Negeri 3 Tanjung Raja Kecamatan Indralaya Kabupaten Ogan Ilir , peneliti mengamati satu kelas yaitu kelas VIII. 2 sebagai subjek penelitian. Berdasarkan hasil pengamatan peneliti melalui tahap-tahap dalam pengumpulan data dan analisis data, guru melakukan belajar mengajar sesuai dengan ketentuan dalam pembelajaran.

Pada tahap persiapan guru menyiapkan RPP, Silabus yang telah guru susun berdasarkan Kurikulum , Sebelum melaksanakan pembelajaran menggambar motif batik guru menanyakan kehadiran siswa dan memotivasi siswa sebelum pembelajaran berlangsung. Pembelajaran menggambar motif batik pada siswa kelas VIII. 2 dilakukan sesuai dengan kurikulum yang telah di sesuaikan dengan keadaan siswa, dan hasil belajar siswa ternyata lebih dari 80\% siswa telah mencapai nilai standar yang diinginkan dimana nilai standar yang ditentukan oleh pihak sekolah SMP Negeri 3 Tanjung Raja terhadap pelajaran seni budaya adalah 70 . 

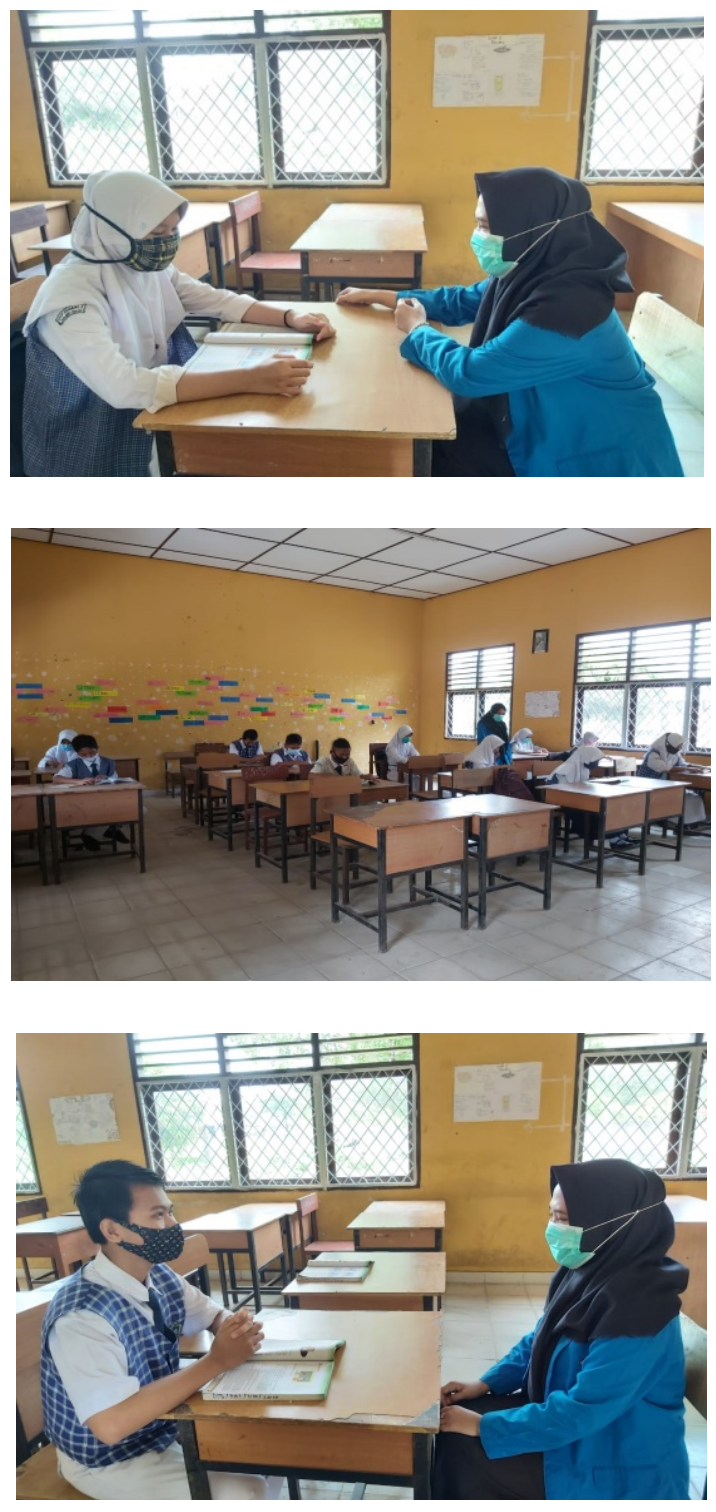

Hal ini membuktikan bahwa hasil dari pembelajaran menggambar motif batik dapat di kategorikan Baik. Pada saat mengajar guru berpedoman pada kurikulum yang telah disesuaikan, Sehingga dapat menjadikan siswa mampu untuk menyerap pembelajaran yang sudah diberikan.

Tahap awal, Peneliti melakukan observasi terhadap guru dan siswa dengan mengamati kesiapan, pelaksanaan dan melakukan wawancara tentang pembelajaran menggambar motif batik pada siswa kelas VIII SMP Negeri 3 Tanjung Raja. Peneliti mengamati tahap persiapan pada Rencana Pelaksanaan Pembelajaran (RPP) yang telah disusun guru sebelumnya, dari RPP tersebut dapat disimpulkan bahwa persiapan guru sebelum mengajar sudah baik, hal ini berdasrkan apa yang telah disusun guru sesuai dengan apa yang di laksanakan pada proses pembelajaran.

$$
\text { Pada tahap pelaksanaan }
$$

pembelajaran, guru membuka proses belajar dengan mengucap salam, memeriksa daftar hadir siswa, menyampaikan informasi Kompetensi Dasar yang akan dicapai, serta memberi motivasi dan apersepsi kepada siswa. Setelah itu pembelajaran selanjutnya merupakan kegiatan inti dari proses pembelajaran yaitu guru menjelaskan tentang pengertian batik, macammacam batik dan cara menggambar motif batik selanjutnya guru memberi peluang untuk siswa bertanya tentang materi yang belum di mengerti.

Berdasarkan hasil pengamatan yang peneliti lakukan kepada siswa, terhadap materi pelajaran menggambar motif batik menunjukkan bahwa siswa mampu mengikuti pelajaran dengan baik sehingga siswa berperan aktif dalam melaksanakan proses belajar mengajar di dalam kelas. Sedangkan hasil pengamatan yang dilakukan peneliti kepada guru menunjukkan bahwa benar guru telah melakukan pembelajaran menggambar motif batik pada siswa kelas VIII SMP Negeri 3 Tanjung Raja dengan Rencana Pelaksanaan Pembelajaran (RPP) yang telah disusun.

Berdasarkan uraian di atas dapat disimpulkan bahwa pembelajaran menggambar motif batik pada siswa kelas VIII SMP Negeri 3 Tanjung Raja sudah berlangsung dengan baik, dan komunikasi antara guru dan siswa terjalin dengan baik pula sehingga siswa mampu menyerap pelajaran yang 
telah diberikan guru dan siswa telah mencapai nilai dengan baik.

\section{KESIMPULAN}

Berdasarkan hasil penelitian dan pembahasan dapat disimpulkan bahwa pembelajaran menggambar motif batik efektif dan dapat meningkatkan hasil belajar siswa pada mata pelajaran seni budaya di kelas VIII SMP Negeri Tanjung Raja tahun pelajaran 2020/2021 dengan jumlah siswa sebanyak 36 orang.

Para siswa telah mampu dalam menggambar berbagai motif batik hal ini dapat dilihat dari hasil observasi siswa yang menunjukkan hasil baik dan dapat disimpulkan hampir keseluruhan siswa dapat melakukan proses pembelajaran dengan maksimal sesuai yang diharapkan.

\section{DAFTAR PUSTAKA}

Aunurrahman. (2019). Belajar dan Pembelajaran . Bandung : Alfabeta

Apsari Ayu Ratih dkk. (2019). Belajar dan Pembelajaran. Depok: PT Raja Grafindo Persada

Arikunto, Suharsimi. (2013). Prosedur Penelitian Suatu Pendekatan Praktek. Jakarta: PT Rineka Cipta.

Arikunto, Suharsimi. (2010). Prosedur Penelitian Suatu Pendekatan
Praktek. Jakarta: PT Rineka Cipta.

Denzin Lincon. (2018). Prosedur Metode Kualitatif. Bandung: Rosdakarya

Djamarah. (2011). Psikologi Belajar. Bandung: Rineka Cipta

Hamalik Oemar. (2004). Belajar dan Pembelajaran. Jakarta: Bumi Aksara

Kerlinger. (2002). Metode Penelitian Kualitatif dan Kuantitatif. Jakarta: Rineka Cipta

Miles, B. M. dan Michael Huberman. (1992). Analisis Data Kualitatif Buku Sumber Tentang Metodemetode Baru. Jakarta: UIP

Moh. Suardi. (2018). Belajar dan Pembelajaran. Yogyakarta : Parama Ilmu

Mudjiono dan Dimyati. 2013. Belajar dan Pembelajaran. Jakarta : Rineka Cipta

Retno SA, Dwi. (2004). Gambar Ornamen. Makalah.

Sari, Pandan Rina. (2013). Keterampilan Seni Batik untuk Anak. Solo: Arcita.

Soetedja, Zakarias Sukarya. (2007). Ilmu dan Aplikasi Pendidikan Seni. Bandung: Imtima UPI.

Sugiono. (2017). Metode Penelitian Kuantitatif, Kualitatif, dan R\&D. Bandung: Alfabeta

Pamadhi, Hadjar dkk. (2008). Pendidikan Seni di SD. Jakarta: Universitas Terbuka. 